毛髪コンディショニング剤用 ポリマー

\author{
別府 耕次・小宮 薰 \\ 旭電化工業株式会社 研究開発本部油剂開発研究所 \\ （テ116 東京都荒川区東尾久 8-4-1）
}
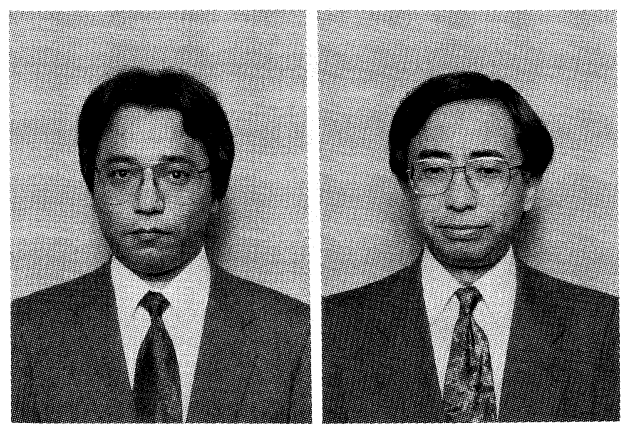

\title{
Polymers for Hair Conditioning Agents
}

Kohji Beppu and Kaoru KomiYA

Organic Chemicals Development Laboratory,

R \& D Division, Asahi Denka Kogyo K.K.

(8-4-1, Higashi-ogu, Arakawa-ku, Tokyo, ₹116)

Many different polymers are used in the cosmetic industry and many new ones have been developed through application of new synthetic technology.

Polymer applications include thickeners emulsifiers, moisturizing agents, and conditioning agents, owing to properties such as surface activity, gelling and rheology.

The reasons why the structures and features of the polymers make them suitable for use as hair conditioning agents are discussed along with trends in the development of new hair conditioning agents. New polymers with multifunctions should find increasing application as hair conditioning agents, in the future.

\section{1 はじめに}

香粧品に使用されているポリマーの種類は, 天然ポリ マーから合成ポリマーまで多種にわたっている。たとえ ば, 増粘剤としてアラビアゴム, トラガント, カラギー ナン, キサンタンガム, ゼラチン, 硫酸コンドロイチン ニナトリウム等の天然ポリマー, メチルセルロース, カ ルボキシメチルセルロース, ヒドロキシエチルセルロー ス，コメデンプン，コムギデンプン，アルギン酸ナトリ ウム, アルギン酸プロピレングリコール等の半合成ポリ マー, ポリビニルアルコール, ポリビニルピロリドン, ポリアクリル酸ナトリウム, カルボキシビニルポリ マー, ポリエチレングリコール, ポリオキシエチレンー ポリオキシプロピレン共重合体等の合成ポリマーが使用 され, 乳化剂としてはカゼイン, エラスチン等のタンパ ク質, 糖タンパク, アルギン酸塩等の天然多糖類, セル ロース誘導体のような天然ポリマーやポリビニルアル コール, ポリアクリル酸ナトリウム, ポリエチレンーポ リプロピレン共重合体等の合成ポリマーが使用されてい る。また, これらのポリマーは增粘剂, 乳化剂としての

連絡者: 別府耕次
機能の他に結合剂, 保湿剤, コンディショニング剤等と して香粧品の用途に幅広く使用されている。

この中でコンディショニング剤は, シャンプー, リン ス，トリートメント等の市場の大きい製品群に欠くこと のできない成分である。これら製品群は最近若者層にお ける毛髪の漂白, 染色, シャンプー回数の増大により, リンス効果のあるシャンプーが開発され急速に需要が拡 大した。それに伴い, シャンプー, リンス等の処方が見 直されると共にコンディショニング剤の開発も盛んに なってきている。

ここではコンディショニング剂, 特に毛髪コンディ ショニング剂用ポリマーの近年の開発および応用につい て述べたい。

\section{2 コンディショニング剂の種類}

コンディショニング剤は大きく分類してカチオン界面 活性剂, カチオン性ポリマーやシリコーン誘導体, タン パク質誘導体等がある。

カチオン界面活性剤は毛髪を柔軟にし, くし(櫛)通り を良くする効果があるためリンスやトリートメントの主 成分として使用され, その主構造は長鎖アルキル第四級 
Table-1 Cationic polymers for cosmetics.

Natural and modified natural polymers

1) Cationic cellulose

- Copolymer of hydroxyethylcellulose and diallyldimethylemmonium chloride

(Polyquaternium-4)

- Polymeric quaternary ammonium salt of hydroxyethylcellulose and a trimethylammonium substituted epoxide

(Polyquaternium-10)

2) Cationic guar gum

- Guar hydroxypropyltrimethylammonium chloride

Synthetic Polymers

1) Adipic acid/dimethylaminohydroxypropyldiethylenetriamine copolymer

2) Adipic acid/epoxypropyldiethylenetriamine copolymer

3) Poly (methacrylamidopropyltrimethylammonium chloride)

4) Copolymer of acrylamide and $\beta$-methacryloyloxyethyltrimethylammonium methosulfate

5) Polymer of diallyldimethylammonium chloride

(Polyquaternium- 5)

6) Copolymer of acrylamide and diallyldimethylammonium chloride

(Polyquaternium- 6)

7) Methyl and octadecyl dimethylaminoethyl methacrylate quaternized with dimethyl sulfate

(Polyquaternium- 8)

8) Poly(dimethylaminoethyl methacrylate)quaternized with methyl bromide (Polyquaternium-9)

9) Quaternized poly(vinylpyrrolidone/dimethylaminoethyl methacrylate) (Polyquaternium-11)

10) Quaternized poly(ethyl methacrylate/abietyl methacrylate/diethylaminoethyl methacrylate)

(Polyquaternium-12)

11) Quaternized poly(ethyl methacrylate/oleyl methacrylate/diethylaminoethyl methacrylate)

(Polyquaternium-13)

12) Copolymer of acrylamide and ethylmethacryloyloxytrimethylammonium chloride

(Polyquaternium-15)

13) Copolymer of poly(vinylpyrrolidone and methoimidazolinium chloride)

14) Diethylmethylpoly(oxypropylene)ammonium chloride

(Polyquaternium-16)

アンモニウム塩である。しかし, シャンプーのコンディ ショニング剂として用いる場合は, シャンプーの主基材 として使用されるアニオン界面活性剤とコンプレックス を生じ, 沈殿したり洗浄性や泡立ちを悪くするため, ア 二オン界面活性剂に両性界面活性剂や非イオン界面活性 剂等を加えることによってアニオン界面活性剤との相溶 性を高める等の手段がとられる。

タンパク質誘導体等には過加水分解タンパクやアシル 化コラーゲン等があるが，これらは主に毛髪保護剤とし て効果が顕著である ${ }^{1) 。 ~}$

カチオン性ポリマーには毛髪をしなやかにし，しっと り感をあたえる効果がある。カチオン性ポリマーはその 代表的な種類を Table-1 に示したように天然物由来ポ リマーと合成ポリマーがある。力チオン性ポリマーを シャンプーのコンディショニング剤として用いる場合 は，アニオン界面活性剤との相溶性が悪いため, シャン
プーの主基材に両性界面活性剂や非イオン界面活性剂を 用いる等の方法によりシャンプー中に可溶化または分散 させて用いる。カチオン性ポリマーがコンディショニン グシャンプーにおいてコンディショニング性を発揮する 原理は, シャンプー中では可溶化あるいは分散状態で存 在しているが, 洗髪, すすぎ時に水で希釈されることに よりその状態が壊れコンプレックスとして析出し, 毛髪 に物理的，化学的に吸着すると考えられている ${ }^{2)}$ 。 シリコーンは毛髪にすべりやつや(艶)をあたえる優 れた効果を有しており, カチオン性ポリマーとは異なる 感触を与えることから, その誘導体として水溶性シリ コーン, シリコーン乳化物, 有機性シリコーンが開発さ れ，コンディショニング剤として用いられている。 この中でカチオン性ポリマーとシリコーン誘導体のポ リマー型コンディショニング剤は近年，高分子合成技術 の発展に伴い新しい機能を付与したポリマーの合成が可 
能となっており, 新しいコンディショニング剤用ポリ マーの研究開発が盛んに行われている。

以下にコンディショニング剤用ポリマーとして使用さ れているカチオン性ポリマーとシリコーン誘導体につい てその構造と特徴について述べる。

\section{3 カチオン性ポリマーの種類と構造}

\section{1 天然系カチオン性ポリマー}

天然系カチオン性ポリマーの最大の特徴は経口毒性, 皮膚刺激性といった安全性の面ですぐれていることにあ る。その代表的なものにカチオン化セルロースおよびカ チオン化グアーガムがある。

\section{a) カチオン化セルロース}

Fig. -1 にその構造と合成方法について示す。カチオ ン化セルロースはグリシジルトリメチルアンモニウム= クロリドによりヒドロキシエチルセルロースを部分的に 第四級化して合成される。主成分は無水グルコース単位 当たりオキシエチレン基 $\left(-\mathrm{CH}_{2} \mathrm{CH}_{2} \mathrm{O}^{-}\right)$を $1.6 \sim 1.8$ $\mathrm{mol}$, 第四級窒素基 $(\mathrm{N})$ を $0.3 \sim 0.4 \mathrm{~mol}$ 含有している。

カチオン化セルロースの特徵としては, 毛㧞をしっと りなめらかにし, まとめやすくするコンディショニング 効果, くし通りが良くなり, ブラッシングによる毛髪表
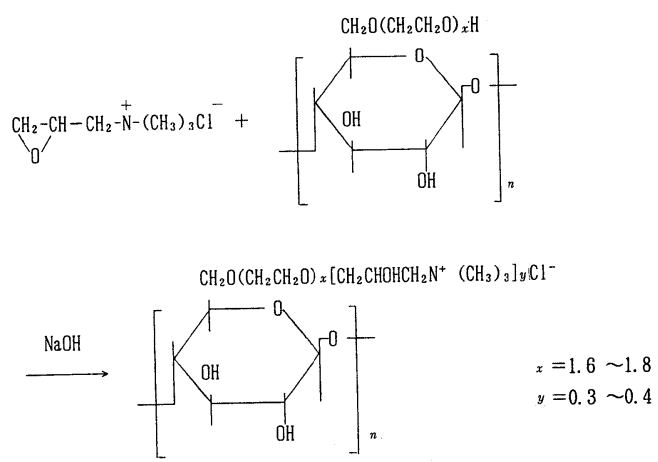

Fig.-1 Structure of cationic cellulose.
面の損傷を防止する毛髪表面の保護効果, ブラッシング による静電気の発生を減少させる帯電防止効果の他に, シャンプーの泡立ちを良くする効果等がある ${ }^{3) \sim 5) 。 ~}$

b) カチオン化グアーガム

カチオン化グアーガムは $\mathrm{D}^{-}$ガラクトースと $\mathrm{D}^{-}$マン ノースの構成比が $1: 2$ で構成されているガラクトマン ナンを原料とし，これにカチオン化剤を反応させて得ら れる。その構造を Fig.-2に示す。

カチオン化グアーガムは原料の特徵を残し, セルロー 誘導体等に比較し高い粘度を示すため, 増粘性効果も ある6)。

\section{$3 \cdot 2$ 合成系カチオン性ポリマー}

合成系カチオン性ポリマーの特徵は, カチオン基一個 当たりの分子量が天然系ポリマーに比へ小さいため, 少 量で高いコンディショニング効果を得ることが期待でき ることにある。また, ジアリルジメチルアンモニウム= クロリド・アクリルアミド共重合体等の様にカチオン性 モノマーと非イオン性モノマーの比率を変えることによ り所望のポリマーを容易に得ることもできる。これら合 成系カチオン性ポリマーの代表的な構造および特徽につ いて示す。

a) アジピン酸/ジメチルアミノヒドロキシプロピル ジエチレントリアミン共重合体

構造を Fig.-3に示す。特徽はほとんどのアニオン界

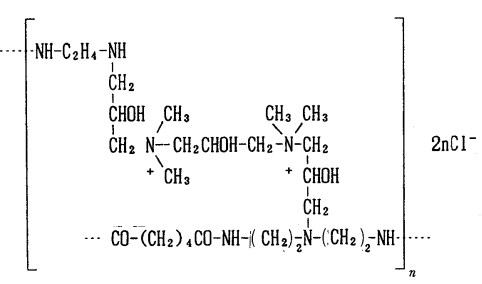

Fig. -3 Structure of adipic acid/ dimethylaminohydroxypropyldiethylenetriamine copolymer.

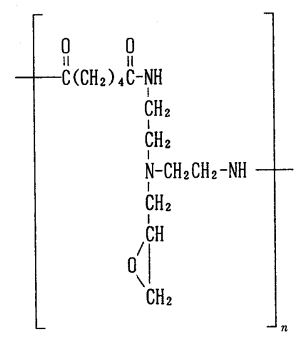

Fig. -4 Structure of adipic acid/epoxypropyldiethylenetriamine copolymer.

Fig. -2 Structure of cationic guar gum. 


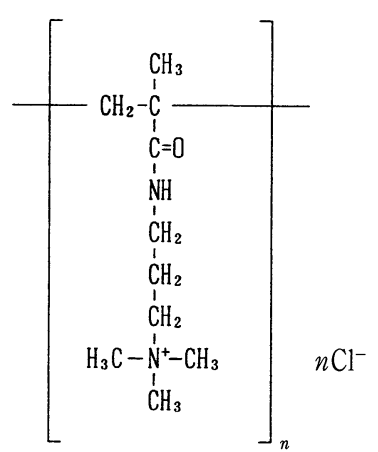

Fig. -5 Structure of poly (methacrylamidopropyltrimethylammonium chloride).

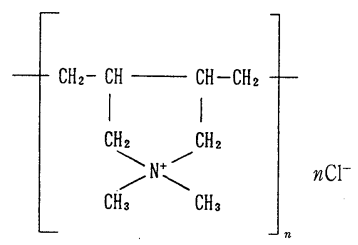

Fig. -6 Structure of polymer of diallyldimethylammonium chloride.

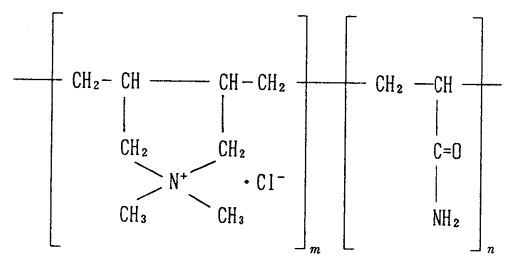

Fig. -7 Structure of copolymer of acrylamide and diallyl dimethyl ammonium chloride.

面活性剂と配合でき，刺激性が少ない）。

b) アジピン酸/エポキシプロピルジェチレントリア ミン共重合体

構造を Fig. -4 に示す。特徴は毛髪への定着性が良好 である7)。

c） ポリメタクリルアミドプロピルトリメチルアンモ ニウムンクロリド

構造を Fig. - - に示す。特徴は毛髪に柔らかで滑らか な感触を与える7)。

d） ポリジアリルジメチルアンモニウムンクロリド

構造を Fig.-6に示す。特徴はコンディショニング性 および保湿性にすぐれる4),5),7)。

e) アクリルアミド/ジアリルジメチルアンモニウム ンクロリド共重合体

構造を Fig.-7 に示す。特徴はすぐれたコンディショ

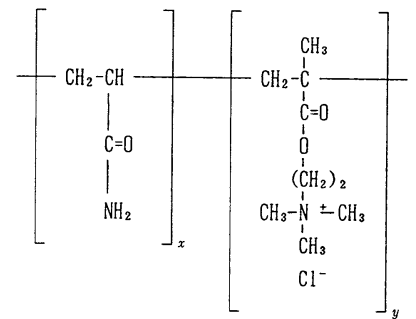

Fig.-8 Structure of copolymer of acrylamide and methacryloyloxyethyltrimethylammonium chloride.

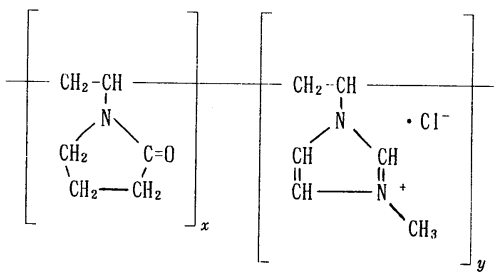

Fig. -9 Structure of copolymer of vinylpyrrolidone and vinylimidazolinium chloride.

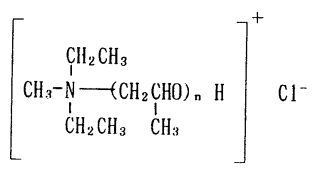

Fig. -10 Structure of diethylmethylpoly (oxypropylene)ammonium chloride.

ニング性と保湿性を有している(4),5),7)。

f）アクリルアミド/メタクリロイルオキシエチルト リメチルアンモニウムニクロリド共重合物

構造を Fig. -8 に示す。特徴は毛髪の湿時および乾燥 時の整髪性, 〈し通りの改善, 泡立ちが良好である ${ }^{8)}$ 。

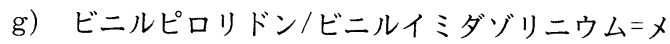
チルクロリド共重合体

構造を Fig. -9 に示す。特徴は毛髪導電性良好で広範 囲の $\mathrm{pH}$ にて使用可能である ${ }^{1), 7) 。 ~}$

h) ジエチルメチルポリ(オキシプロピレン)アンモニ ウムンクロリド

構造を Fig. - 10 に示す。特徴は刺激性が少なく, ア ニオン界面活性剤との相溶性にすぐれる。

これら合成系カチオン性ポリマーの内, 弊社にて製品 化している,

d） ポリ(ジアリルジメチルアンモニウム=クロリド)

e）アクリルアミド/ジアリルジメチルアンモニウム ンクロリド共重合体 
Table-2 Properties of Adekacatioace PD-50.

\begin{tabular}{c|c|c|c}
\hline $\begin{array}{c}\text { Activity } \\
(\%)\end{array}$ & $\mathrm{pH}$ & $\begin{array}{c}\text { Color } \\
(\mathrm{APHA})\end{array}$ & $\begin{array}{c}\text { Viscosity } \\
(\mathrm{cP})\end{array}$ \\
\hline 40 & 6.1 & 30 & 10,000 \\
\hline
\end{tabular}

h) ジエチルメチルポリ(オキシプロピレン)アンモニ ウムンクロリド

についてさらに詳しく説明する。

$3 \cdot 2 \cdot 1$ ポリ (ジアリルジメチルアンモニウムニクロリ ド)

ジアリルジメチルアンモニウム=クロリドのホモポリ マーであるこのポリマーは, 第四級塩窒素基一個当たり の分子量が約 162 と小さく, 少量でも高いコンディショ ニング効果が期待できる。またシャンプーの泡立ちが良 好で, なおかつきめ細かい泡を形成する効果がある。

Table-2 にポリ (ジアリルジメチルアンモニウム=ク ロリド) であるアデカカチオエース PD-50 の物性例と Fig.-11にやし油アルキルベタインに配合したときの ロスマイルス法による泡立ち試験を示す。

このポリマーは高い洗浄力を有するアニオン界面活性 剤やイミダゾリン両性界面活性剤には溶解しない欠点が ある。そこで, 優れたコンディショニング効果を有する このポリマーを, これらの界面活性剤に溶解させる研究 開発が行われている。その一つに, 特定のベタイン系界 面活性剂と特定の界面活性剂との組み合わせにより,ア

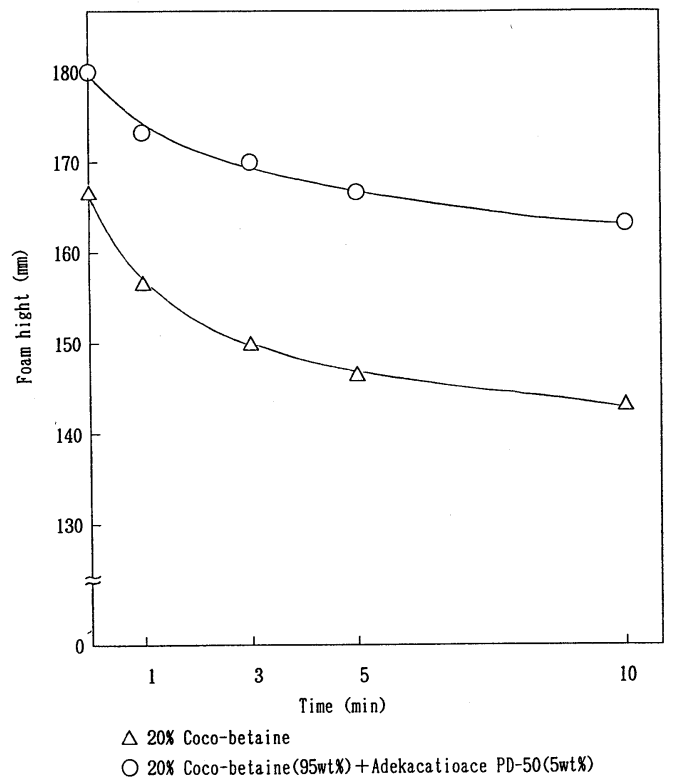

Fig.-11 Foaming test of Adekacatioace PD-50 $\left(0.5 \%\right.$ solution at $40^{\circ} \mathrm{C}$ by Ross-Miles method)
Table-3 Example of recipe of shampoo.

\begin{tabular}{l|c}
\multicolumn{1}{c|}{ Ingredient } & Content (\%) \\
\hline $\begin{array}{l}\text { Triethanolamine dodecyl } \\
\text { poly(oxyethylene) sulfate }\end{array}$ & 8 \\
(3 EO) & 8 \\
Lauramidepropylbetaine & 5 \\
Lauroyl diethanolamide & 1.0 \\
Adekacatioace PD-50 & As requied \\
Perfume, coloring agent & Balance \\
Water &
\end{tabular}

Table-4 Solubility of copolymer of acrylamide (AAm) and dimethyl and diallyldimethylammonium chloride (DM) with anionic surfactant.

\begin{tabular}{c|c}
\hline DM/AAm (wt\%) & Penetrating power* \\
\hline $100 / 0$ & 0.00 \\
$70 / 30$ & 0.00 \\
$60 / 40$ & 0.01 \\
$50 / 50$ & 0.20 \\
$40 / 60$ & 0.98 \\
$30 / 70$ & 0.99 \\
\hline
\end{tabular}

Penetrating power of $25 \%$ sodium dodecylpoly (oxyethylene)sulfate (3 EO) [99.5 wt\%] with copolymer $[0.5 \mathrm{wt} \%]$, Blank $=1.00$

二オン界面活性剂やイミダゾリン両性界面活性剤への溶 解が可能となることが報告されている。これはまたすす ぎ時のコンプレックスの析出性が良好でコンディショニ ング効果に優れた洗浄剂組成物となる ${ }^{9)}$ 。その処方例を Table-3 に示す。

$3 \cdot 2 \cdot 2$ アクリルアミド/ジアリルジメチルアンモニウ ムニクロリド共重合体

このポリマーは，ジアリルジメチルアンモニウム=モ ノマーにアクリルアミドモノマーを共重合させたもので あり, 非イオン性のアクリルアミドを任意に共重合させ ることにより所望のカチオン性の性質を調整でき, ポリ (ジアリルジメチルアンモニウムニクロリド）の欠点で あったアニオン界面活性剂との溶解性を改善できる所に 特徵がある。

Table-4 にジアリルジメチルアンモニウム=クロリド とアクリルアミドのモノマー比を変えて共重合させ, ア 二オン界面活性剤〔硫酸ドデシルポリ(オキシエチレン) =ナトリウム : $3 \mathrm{EO}$ 〕 と配合した時の溶解性データを示 す。製品としてはアデカカチオエース PDA-245をはじ め各種品揃えされている。

Table-4 より, アクリルアミドの重量比が 50 wt \% 以上において, アニオン界面活性剂との溶解性が向上し 
Table-5 Properties of Adekacol CC.

\begin{tabular}{l|c|c|c}
\hline & $\begin{array}{c}\text { Adekacol } \\
\text { CC-9 }\end{array}$ & $\begin{array}{c}\text { Adekacol } \\
\text { CC-36 }\end{array}$ & $\begin{array}{c}\text { Adekacol } \\
\text { CC-42 }\end{array}$ \\
\hline Apearance $\left(25^{\circ} \mathrm{C}\right)$ & $\begin{array}{c}\text { Clear } \\
\text { liquid }\end{array}$ & $\begin{array}{c}\text { Clear } \\
\text { liquid }\end{array}$ & $\begin{array}{c}\text { Clear } \\
\text { liquid } \\
\text { Activity (\%) }\end{array}$ \\
$\begin{array}{l}>98 \\
\text { Specific gravity }\end{array}$ & $>98$ & $>98$ \\
pH & 1.01 & 1.01 & 1.01 \\
Molecular weight & 600 & 1,600 & 2,500 \\
\hline
\end{tabular}

Table-6 Stability of Adekacol CC with anionic surfactant.

( $\bigcirc$ : stable, $\times$ : separated)

\begin{tabular}{c|c|c|c|c|c|c|c|c|c}
\hline & \multicolumn{3}{|c|}{$\begin{array}{c}\text { Adekacol } \\
\text { CC-9 }\end{array}$} & \multicolumn{3}{c|}{$\begin{array}{c}\text { Adekacol } \\
\text { CC-36 }\end{array}$} & \multicolumn{3}{c}{$\begin{array}{c}\text { Adekacol } \\
\text { CC-42 }\end{array}$} \\
\hline Content $x \%$ & $3 \%$ & $6 \%$ & $9 \%$ & $3 \%$ & $6 \%$ & $9 \%$ & $3 \%$ & $6 \%$ & $9 \%$ \\
\hline $40^{\circ} \mathrm{C}$ & $\bigcirc$ & $\bigcirc$ & $\bigcirc$ & $\bigcirc$ & $\bigcirc$ & $\bigcirc$ & $\bigcirc$ & $\bigcirc$ & $\bigcirc$ \\
$0{ }^{\circ} \mathrm{C}$ & $\bigcirc$ & $\bigcirc$ & $\bigcirc$ & $\bigcirc$ & $\bigcirc$ & $\bigcirc$ & $\bigcirc$ & $\bigcirc$ & $\bigcirc$ \\
\hline
\end{tabular}

Recipe : Sodium dodecylpoly(oxyethylene)sulfate (activity)

Adekacol CC

Water

$10 \%$

$x \%$

Balanc

Condition : $7 \mathrm{~d}$ at $40^{\circ} \mathrm{C}$ and $0^{\circ} \mathrm{C}$

ていることがわかる。

$$
\begin{aligned}
3 \cdot 2 \cdot 3 & \text { ジェチルメチルポリ(オキシプロピレン)アン } \\
& \text { モニウムニクロリド }
\end{aligned}
$$

構造はFig.ー10に示した様に, ポリオキシプロピレ ン鎖を親油基とする第四級アンモニウム塩型ポリマーで
ある。その物性例を Table-5に示す。

特徴としては,

（1）眼や皮膚に対する刺激性が低く，安全性が高 い。

（2）アニオン界面活性剤との相溶性が良好である。

（3）带電防止性に優れている。

等がある。

Table-6 にアニオン界面活性剂〔硫酸アルキルポリ (オキシエチレン)=ナトリウム】との配合系における安 定性デー夕を示すように，アニオン界面活性剂との相溶 性は分子量に関係なく良好である。

安全性については, アデカコール CC-9, CC-36, CC-42 の $1 \%$ 水溶液は, ウサギの眼に対するドレーズ 法の試験で刺激性を示さない。タンパク質変性作用 ${ }^{10)}$ においては代表的な低刺激性界面活性剂であるべタイン 型の両性界面活性剂と同程度であり, 皮虐刺激性は弱い ことが推定される (Table-7)。

\section{4 シリコーン誘導体ポリマー}

シリコーン誘導体ポリマーの特徴は従来のシリコーン のシャンプーの泡立ちや洗浄性に悪影響を与えるといっ た欠点を改良したものである。その代表的な構造と特徴 を以下に示す。

a) ポリエーテル変性シリコーン

構造を Fig.-12 に示す。特徴としては泡立ち良好で アニオン界面活性剤の眼刺激性を軽減する。

b) アミノ変性シリコーン

構造を Fig.-13 に示す。特徵としては, 滑らかさ, つや，くし通りが良好等である。

\begin{tabular}{|c|c|c|}
\hline Composition & A & $\mathrm{B}$ \\
\hline Protein ovalbumin & $0.0225 \%$ & $0.0225 \%$ \\
\hline Test substance & $0.6 \%$ & $0.2 \%$ \\
\hline Anionic surfactant* & - & $0.4 \%$ \\
\hline \multirow[b]{2}{*}{ Test substance } & \multicolumn{2}{|c|}{ Percent denaturation (\%) } \\
\hline & A & B \\
\hline Adekacol CC- 9 & 5 & 45 \\
\hline 36 & - & 26 \\
\hline 42 & - & 24 \\
\hline Lauramidepropylbetaine & 16 & 32 \\
\hline Dodecyldimethylbetaine & 58 & 22 \\
\hline Dodecylimidazoliniumbetaine & 4 & 52 \\
\hline Brank(only anionic surfactant) & 0 & 100 \\
\hline
\end{tabular}

Table-7 Percent denaturation and composition of surfactants for detergents.

Anionic surfactant : $25 \%$ sodium dodecylpoly(oxyethylene) sulfate (3 EO) 


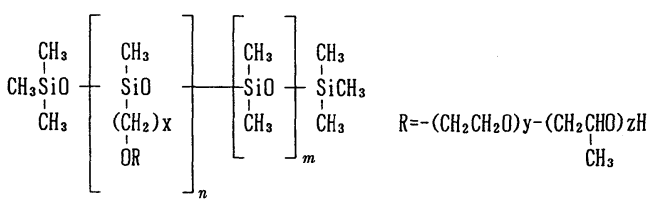

Fig. -12 Structure of polysiloxane polyether copolymer.

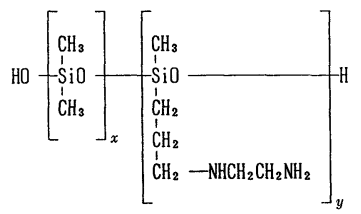

Fig.-13 Structure of silicone polymer endblocked with amino functional groups.

\section{5 最近の特許による開発例}

最近の公開特許（平成 $4 \sim 6$ 年）より, シャンプー, リンスに限定し使用されているポリマーの状況をまとめ た (Table-8)。

近年の傾向としてコンディショニング効果とスタイリ ング効果の両方を向上させる処方およびポリマーの開発 が多くみられる。その中で特徴的な幾つかの例を以下に 示す。

$5 \cdot 1$ シリコーン共重合体

シリコーンは毛髪に優れたはっ水性，滑り性を与える 反面他の基剤との相溶性が悪くスタイリング効果の低下

Table-8 Patents of polymers for shampoos and rinses.

\begin{tabular}{lr}
\hline Cationic cellulose & 9 \\
Cationic silicone & 14 \\
Copolymer of diallyldimethylammunium & 7 \\
Poly(vinylpyrrolidone) & 4 \\
Poly(ethyleneimine) & 10 \\
Acrylic polymer & 3 \\
Cationic guar gum & 2 \\
\hline
\end{tabular}

や手触り感において油っぽいという欠点があった。それ を改良するためシリコーンマクロモノマーと種々の親水 性モノマー，疎水性モノマーとを共重合することが行わ れている。これらは，毛髪に優れた光沢，艶，滑らかな 感触を与え, 更にはセット性等のスタイリング効果と, 柔軟性やくし通り性等のコンディショニング効果を与え ることを特徴としている $($ Table-9)。

\section{$5 \cdot 2$ シリコーンとカチオン性ポリマーの配合}

シリコーン共重合体と同様に，シリコーンとカチオン

性ポリマーを配合することにより，シリコーンの特性と カチオン性ポリマーの特性を併せ持つことを特徴として いる (Table-10)。

\section{$5 \cdot 3$ 両性モノマー/カチオンモノマーおよびアニオン} 性モノマー共重合体

くし通り性および感触性良好等のコンディショニング 性を有すると共にアニオン界面活性剤との相溶性を改良

Table-10 Patents of silicone polymer with cationic polymer.

\begin{tabular}{c|l}
\hline Jpn. Kokai & \multicolumn{1}{|c}{ Structure } \\
\hline '93-65217 & $\begin{array}{l}\text { Polydimethylsiloxane and diallyl- } \\
\text { dimethylammonium chloride }\end{array}$ \\
\hline '93-179297 & $\begin{array}{l}\text { Silicone and copolymer of diallyl- } \\
\text { dimethylammonium chloride and } \\
\text { anionic monomer }\end{array}$ \\
\hline
\end{tabular}

Table-11 Patents of copolymer of amphoteric, cationic and anionic monomer.

\begin{tabular}{l|l}
\hline Jpn. Kokai & \multicolumn{1}{|c}{ Structure } \\
\hline '93-246828 & $\begin{array}{l}\text { Polymer of } N \text {-alkylacrylamide, } N- \\
\text { vinylpyrrolidinone, diallyldimethyl- } \\
\text { ammonium chloride, diallylamine, } \\
\text { acrylic acid and vinyl acetate. }\end{array}$ \\
\hline \multirow{5}{*}{$94-107526$} & $\begin{array}{l}\text { Polymer of acrylamide, diallyl- } \\
\text { dimethylammonium chloride, acry- } \\
\text { lic acid and 2-acrylamide-2-meth- } \\
\text { ylpropanesulfonic acid }\end{array}$ \\
\hline
\end{tabular}

Table-9 Patents of copolymer of silicone.

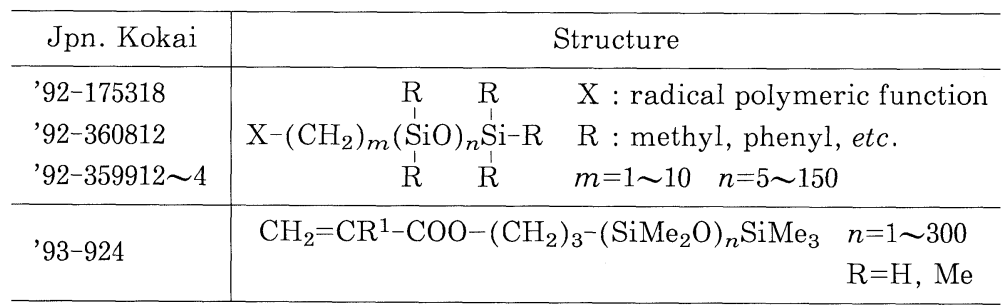


したことを特徴としている (Table-11)。

\section{6 今後のコンディショニング剂用ポリマー について}

最近の特許にみられる様に今後のコンディショニング 鼡に要求される機能はコンディショニング効果のみなら ず，スタイリング性を兼社備えたものであろう。そのた めに従来のポリマーで成しえなかった機能を持たせた新 規モノマーの開発や，安全性はもとより環境への影響の 少ない生分解性のポリマー等の新規基材の開発が必要で あると思われる。

[平成 7 年 (1995 年) 1 月 18 日受理]

\section{文献}

1) 刚米孝雄, 洗浄設計, 1987 (34), 74

2) E. D. Goddard, R. B. Hannan, J. Am. Oil Chem. Soc., 54, 561 (1977)

3）柳川琢磨, 橋本 茂, Fragrance J., 1978 (31), 77

4) B. Idson, W. Lee, Cosmetics \& Toiletries, 98 (10), 41 (1983)

5) A. L. L. Hunting, Cosmetics \& Toiletries, 99 (6), 57 (1984)

6) 堀江和生, Fragrance J., 21 (12), 69 (1993)

7) R. Y. Lochhead, Cosmetics \& Toiletries, 103 (12), 23 (1988)

8）刈米孝雄, 油脂, 47 (10), 61 (1994)

9）鈴木康夫, 小林誉宜, 矢作和行, 公開特許, 平 4-108, 724

10）宮澤 清, 小川正孝, 光井武夫, 粧技誌, 18 (2), 96 (1984) 